\title{
Determinants of Failures of Local Agricultural Firms in Cameroon: The Case of Soderim, Ugicaes and Ugirilcopam in the Mbo Plain (Cameroon)
}

\author{
Ediamam Epalle Guy Marcel*, Usongo Patience Ajonina* \\ Department of Geography, University of Buea, Buea, Republic of Cameroon \\ Email address: \\ guymarcelediamamepalle@gmail.com (E. E. G. Marcel), pusongo@yahoo.com (U. P. Ajonina) \\ ${ }^{*}$ Corresponding author
}

To cite this article:

Ediamam Epalle Guy Marcel, Usongo Patience Ajonina. Determinants of Failures of Local Agricultural Firms in Cameroon: The Case of Soderim, Ugicaes and Ugirilcopam in the Mbo Plain (Cameroon). International Journal of Business and Economics Research. Special Issue: Risk Management in Public Sector Organizations. Vol. 10, No. 2, 2021, pp. 76-86. doi: 10.11648/j.ijber.20211002.13

Received: June 29, 2020; Accepted: March 5, 2021; Published: March 30, 2021

\begin{abstract}
Despite significant financial and technical resources mobilized by the State through financial institutions, local development has not followed the investment curve and the peasantry is still drowned in underdevelopment. In the 1960s, the State of Cameroon launched the five-year development plan where, one of the major components is the development of structuring projects keeping in mind the construction of agro-industrial complexes to serve as models for small farms placed under their supervision. Therefore, specialized development companies (SODES) such as SODERIM, UGICAES and UGIRILCOPAM were created and received 1,200,000,000FCFA, 20,000,000FCFA and 177,000,000FCFA respectively and $5,200,000 \mathrm{FCFA}$ grants each per year. However, it is difficult nowadays to appreciate the input of this funding into local development. This study aims at evaluating the contribution of agricultural project financing to local development and its sustainability in the Mbo plain. We used empirical observation based on semi-directive interviews with the managers of SODERIM, UGICAES and UGIRILCOPAM firms (former employees), and questionnaire administration to peasants and agricultural extension agents as well as the exploitation of secondary data collected from the Sub-Divisional Delegation of Agriculture, registers of these firms, and field observation. Results show that SODERIM, UGICAES and UGIRILCOPAM did not foster the development of the Mbo plain and all went bankrupt when funding stopped since they were unable to selffinance. The determinants of these local agricultural firms failure were both external and internal. The infrastructural, political and socio-economic aspects have remained dormant. Thus, financing has not stimulated a new peasant dynamic in an autonomous framework.
\end{abstract}

Keywords: Determinants, Failures, Local Agricultural Firms

\section{Introduction}

The rural world, despite urban growth, accounts for about three-quarter of the population. It generates $70-80 \%$ of employment, $40-60 \%$ of GNP, $80-90 \%$ of food supply, $80-90 \%$ of export earnings World Bank [1]. Thus, from the dawn of independence, agricultural and rural financing is generally in this part of the world, an important component of the development strategies adopted by less developed countries [2]. In these countries, many rural financing policies and institutions have been tested since the colonial period, resulting to the mobilization of a diverse range of actors since the 1990s.
But since independence, have the rural financing policies tested in Cameroon made it possible to build real local development? Financing policies meant to foster rural development, have not had the expected results or the results are mitigated for the less we can say. Whether it is the financing of peasant organizations or public agro-industrial companies, it is difficult to identify on the field, the achievements of the said financing. They rely on subsidies. Thus, the main research question is how can we understand and explain the failure of agricultural firms; Soderim, Ugicaes and Ugirilcopam in Cameroon? From this main question, the sub research questions are 1- What are the internal 
determinants of the failure of Soderim, Ugicaes and Ugirilcopam in Cameroon? 2- What are the external determinants of the failure of Soderim, Ugicaes and Ugirilcopam in Cameroon? What are the consequences of this failure on the local area ? The objective of this study is to assess the determinants of the failure of agricultural project financing to local development. In this work, we shall examine the context of the creation of SODERIM 1 (structuring/strategic), UGICAES 2 and UGIRILCOPAM $^{3}$ (local level), their level of participation in local development, the establishment of the record of their bankruptcy, analysis of the determinants of their failure, the consequences of this failure and the lessons learned to avoid such project failure in the future.

\section{Literature Review}

Determinants of failure is a relatively contemporary concept viewed in different ways by researchers. Different approaches have been used to address the issue.

\subsection{Approach Through Factors of Development Companies Bankruptcy}

While studying the disengagement of the State from SODERIM and the emergence of new actors involved in the development of the Sanzo-Santchou subdivision (West Region of Cameroon), Kuou [3] focuses on the presentation of the activities of new development actors. He assesses their difficulties. Among the factors that led to the closure of this company, he blames the poor management, lack of missions to control, monitor and evaluate the use of subsidies granted by the State to the company. Malango [4], evaluating "Technological theories explaining the crisis of Congolese public enterprises", starts from historical causes which prove that, public companies went bankrupt because the colonial system did not favour "the creation of a middle class of entrepreneurs with sufficient mastery of the technologies used" with systemic causes also accounting for the failure of Congolese public enterprises. In his view, responsibility lies with the globalized capitalist system which, through the dynamics of short, medium and long-term loans to poor countries through the "Bretton Woods" institutions, makes public investment in southern countries almost nonexistent. Moreover, the members of the management team of these companies who, conscious of the provisional aspect of their functions, bring everyone back to the present by anticipating the maximisation of economic utilities, hence the multiplication of embezzlement and low wages.

\subsection{Approach Through the Actors Games}

Ediamam [5], working on the land issues of the former SODERIM, focused on the landownership of this space.

\footnotetext{
${ }^{1}$ SODERIM"Rice Development Company in the Mbo Plain".

${ }^{2}$ UGICAES"Union of Santchou Farmers and Ranchers Common Initiative Groups".

${ }^{3}$ UGIRILCOPAM3 "Union of Common Initiative Groups of Rice Farmers for the Fight against Poverty in Menoua Rural Areas"
}

Particularly, the 4050 ha allocated to the defunct company and; through legal texts, the current status of these lands, the causes of the greed of these lands by the actors and the strategies implemented. He starts with the logic and role of each actor to show the extent of the lust that emerges for this space. He presents the institutional vacuum left by the State which, after the closure of SODERIM, did not define a real status for the lands. The indigenous, the Mbo population who in turn, claimed the right of legitimate ownership over these lands, and the foreign land seekers who sometimes rent out and sometimes buy from the natives without worrying about the possible return of the State. However, he did not give enough thought to the position of the former company employees who so far claim some part of this heritage. This ambiguous situation prompts us to wonder how the people who are currently exploiting the lands of the former SODERIM organize themselves to live in harmony despite their contradictory logics? Do these actor games lead to conflicts? If so, how do they deal with them? Feudjeu [6] were interested in the diversification of crops in the exSODERIM domain. For him, the disappearance of SODERIM has favored the development of a peasant organization (PO) called the union of GICs of producers, farmers and breeders of Santchou (UGICAES); whose objective was to relaunch polyculture on the estate and anticipate the issue of food insecurity which would set in after the closure of SODERIM. Moreover, this PO has showed its know-how for more than five years now, before in its turn, experiencing a collapse and a total failure. Elong [7], analyzing the peasant response to state agricultural firms failure, links up the 1980s crisis and the State withdrawal from the supervision of the rural world with the emergence of peasant associations. This flowering of POs is reflected in the multiplication of GICs throughout the national territory. According to him, the dynamism of these GICs ensures cohesion at the village level and constitutes a considerable asset in the process of participatory development. As such, he writes: "GICs are new training schools in production and marketing techniques" for farmers. Here they learn to unite to champion their causes, create innovations in order to improve their situation.

\subsection{Approach Through the Peasant Response to the Crisis}

According to Suleiman [8], financing agriculture, the primary and fundamental sector of the economy remains the best option for economic development and deserve no less interest. Kengne [9], in his work identifies a new type of actor and analyzes the extent of their contributions to the Cameroonian countryside through their investments (creation of plantations, development of roads, etc.). It is completed with Elong \& Mbanga [10], who highlights the role of community participation in rural development in the department of Ngo-Ketundjia in the North West Region of Cameroon. He focuses on the supervision of local populations by international organizations such as the national participatory development program (N.P.D.P.). In the same perspective, the United Nations Development Program 
(UNDP) in its 2017 report mentions that "the success of poverty eradication depends more on the ability of populations to formulate their demands and to mobilize for collective actions". Fongang [11] examines the changes in the Bamileke agricultural sector (Cameroon) studied through its actors and shows how the peasants of the West Region have reconstituted themselves after the crisis. The multiplication of peasant organizations and the intensification of food production are two strategies through which these populations have responded to the coffee crisis.

\subsection{Conceptual Model of the Study}

A close examination of the concept of determinants of failure leads to the establishment of the conceptual model illustrated on figure 1 .



Source: Computed by the author, 2020

Figure 1. Conceptual model of determinants of failure.

\section{Material and Method}

This study is based on empirical observation found on semistructured interviews with officials of Divisional Delegation of MINADER in Menoua division, former companies' managers, and questionnaire surveys of farmers and Agricultural Extension Agents. The questionnaire was administered to SODERIM, UGICAES, and UGIRILCOPAM former peasant's workers. We chose the respondents taking into account the representativeness of the different GICS. We have also chosen the non-probabilistic sampling method. The questionnaire aim to understand the logic behind, actions of these companies' members. Legislative and regulatory texts analysis has been done to understand law governing these firms organization. Interview were conducted in order to have an appraisal on company's management from formers employees. Secondary data were obtained from Santchou District Delegation of Agriculture, and from the archives of the defunct Soderim. The data were analyzed in Excel in order to illustrate the evolution of subsidies and distribution of expenditures, the map drawn up in ARCGIS to show through maps, the consequences of this failure.

\section{Results and Discussion}

The Determinants for the Failure of SODERIM, UGICAES and UGIRILCOPAM

In the mid 80s, Cameroon's economy entered recession phase, mainly due to a decline in world prices of her main 
export products: coffee, cocoa and oil. Most of the development companies created by the State went bankrupt. Several reasons seem to explain this bankruptcy the internal and external determinants. With regard to SODERIM: the mismanagement of funds, the economic crisis of the 80 s and the disengagement of the State, are some of the reasons for the termination of this firm.

\subsection{The Case of SODERIM}

\subsubsection{The Internal Determinants for the SODERIM Failure}

\section{i. The Context of Creation of Rice Development Company in the Mbo Plain (SODERIM)}

In favour of enhancement of its various fields and animated by a national and international world food deficit situation; the State created the MIDERIM which later became SODERIM with 4050ha of land for its activities, following a Presidential Decree No. 73/235 of 09 May, 1973.

Internationally, between 1972 and 1973, for the first time in more than twenty years, global food production declined as a result of adverse weather conditions and poor harvests in several parts of the world Ediamam [12]. The FAO conference in 1973 called for additional assistance to strengthen food production and establish national food reserves in some cases. The objectives of the international commitment included, special assistance to developing countries in increasing their food production and adopting national policies on grain stocks. Echo of FAO resolutions has found in Cameroon a favorable ground through Law No. 69/L9/9 of 11 June 1969, in which the State fixed the regime of intervention structures in rural areas. These are development companies created by decree and subjected to State control at all levels with general land management policies. Almost all their acronyms start with SODE followed by the name of the agricultural sector or product promoted for instance: SODECOTON (Cotton Development Company), SODERIM to name a few.

At the national level, the State implemented a supervision policy for rural world in the second five-year development plan (1967-1971) to compensate for the food deficit known as the "Green Revolution". This plan included agro-industrial complexes establishment to serve as models for small-scale farmers under their supervision which favoured a more sustainable migration from densely populated areas to sparsely populated ones [13].
Following feasibility studies of the Mbo plain development by SCET and successful tests carried out by the Research Institute of Agronomic Studies (RIAS) in the 70s, the Cameroon government created in May 1973 the MIDERIM which benefited from allocation asset (asset of tangible, intangible or real estate, given by the State). However, SODERIM; the lamp light that made West Region of Cameroon proud, crumbled due to the economic crisis. It was dissolved by a presidential decree of 08 September 1995 and liquidated in 1998. The State then encouraged agricultural activity sustainability and land exploitation through private operators. Thus, peasant organizations gathered within UGICAES to continue from where SODERIM ended but for how long?

\section{ii. Mismanagement of Funds Allocated to SODERIM}

More than half of the grants were used in 1989 even before the company completed half of the project Kuou, [3]. Funds mismanagement resulted in both misappropriation of funds allocated for the company's activities, improper allocation of funds and exaggerated money use for advertisement. This is in line with Eze, [18] Who studying agricultural financing in Nigeria, found that "though the government has made serious efforts at making good agricultural policies through schemes, programs and institutions, it has not been able to back them up with adequate budgetary allocation and financing coupled with corruption in the execution of the policies",.

\section{iii. Misappropriation of Such Funds}

When it was created, the total capital planned for the activities was 15, 504,200,000 CFA. This huge sum was accompanied by the travel and housing conveniences, aimed at making the leading peasant stay, comfortable. However, with the virtual absence of control missions, project monitoring and evaluation, funds were poorly managed and misdirected by the company directors. In 1985, the first Cameroonian director from his arrival, proceeded by dismissing eight staff members, which thus decreased from 153 to 145 and the non-payment of employees. According to him, it was about reducing the company's expenses. In addition, much of the funds were used for purposes other than those related to the company development.

To better understand the extent of embezzlement, we refer to Table 1 which shows the proportion of funds misused in comparison to allocated funds by the State.

Table 1. Expenditures distribution by amount of grants received by Soderim.

\begin{tabular}{llll}
\hline Years & $\begin{array}{l}\text { Annual grants allocated by the State } \\
\text { (in FCFA) }\end{array}$ & $\begin{array}{l}\text { Amount used for the activities of the } \\
\text { company (in FCFA) }\end{array}$ & $\begin{array}{l}\text { Amount of money used to unknown } \\
\text { destination (in FCFA) }\end{array}$ \\
\hline $1982-83$ & 600000000 & 398984073 & 201015927 \\
$1983-84$ & 100000000 & 464021085 & 535078015 \\
$1984-85$ & 600000000 & 339236665 & 360763336 \\
$1985-86$ & 600000000 & 427408432 & 172591568 \\
$1986-87$ & 300000000 & 180477038 & 69522962 \\
$1987-88$ & 150000000 & - & - \\
Total & 2950000000 & 1710127292 & 1239872962 \\
\hline
\end{tabular}

Source: SODERIM activities report, 1993 cited by Kuou 2007. 
Table 1 Shows the amount of money embezzle by company's executives in less than ten years functioning. Almost $49 \%$ of the total amount was used for unknown, unjustified and unproductive purposes. Thus, from 1982 to 1988, the year when State subventions ended, money misappropriation reduced from $49.5 \%$ to $38.52 \%$. Whenever embezzlement cases were found, the then director was simply suspended and replaced, with no other procedures for recovering embezzled funds.

\section{iv. Early Purchase of Equipment and Machinery}

This is the use of funds for premature purchase of inappropriate equipment for the enterprise. A few years after its creation, in 1975 , a rice Sheller with a capacity of 12,000 tons of paddy per year was purchased for 80.075 million FCFA and installed. However, during the same period, the company produced less than 500 tons of paddy needed to make machine operational. The company was obliged to import the paddy rice from the Tonga production unit for shelling. In addition, while peanut cultivation was still being experimented by the company, a peanut sheller had already been purchased. This could not be used unfortunately because; the peanut cultivation project was abandoned. To get an idea of these early-built firms, we refer to figures 2 and 3.

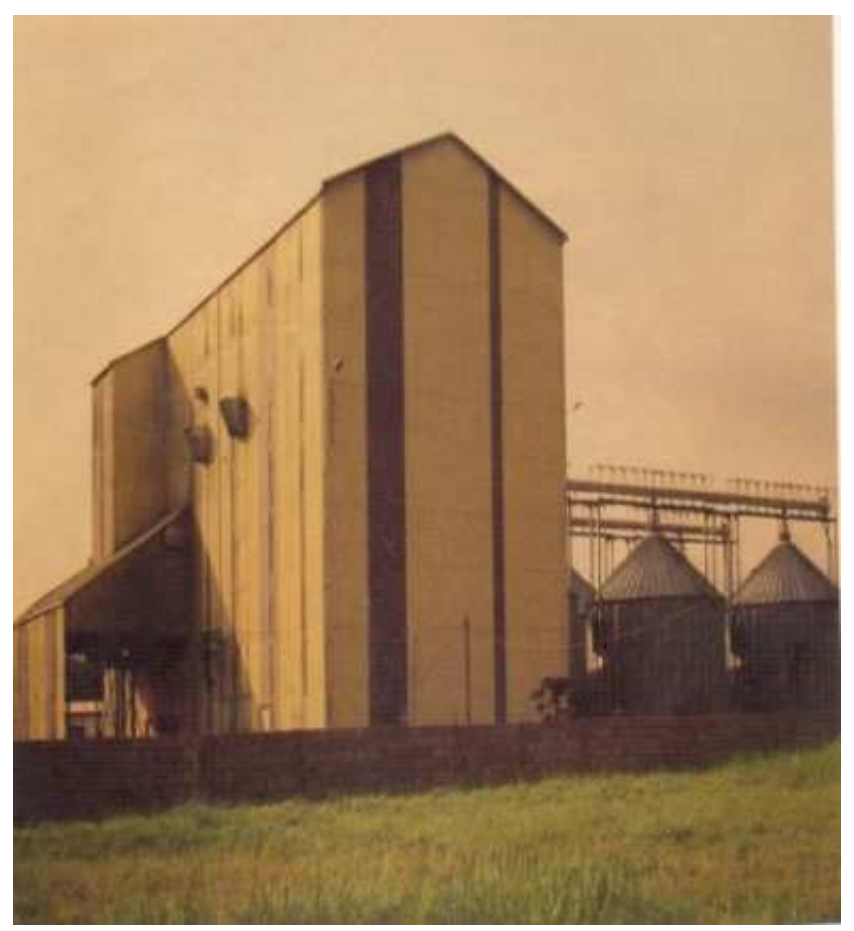

Figure 2. The premises of rice storage.

Figure 2 shows the premises of the storage unit whose $22 \mathrm{~m}$ high metal structures cover a floor area of $750 \mathrm{~m}^{2}$. The premises of the rice mill unit Figure 6 (height $15 \mathrm{~m}$, floor area $\left.900 \mathrm{~m}^{2}\right)$. To this we add the residential buildings of the management staff and a sheller with a capacity of 12000 tons.

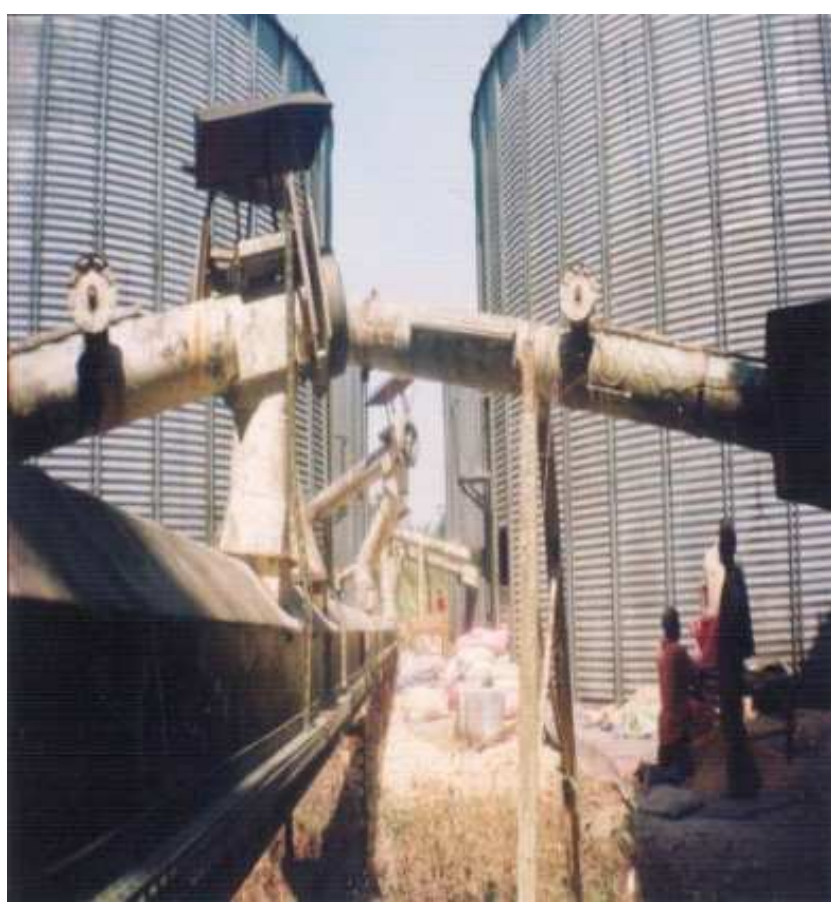

Author's work, 2017.

Figure 3. The rice mill units.

v. The Use of Exorbitant Sums of Money for Advertisement

At this level, there is a visible paradox because, during its first years of existence when it needed to be known and attract buyers and investors, SODERIM did not advertise. It was from 1987, when the company was already sufficiently well-known at the national level, that advertisement intensified, at the heavy cost investments. For example, on 20/06/87, 1417500FCA were used for the broadcast of a program on Cameroon Radio and Television (CRTV); two months later, on 30/08/87, 3,052,225FCFA were still spent through the same frame of advertisement.

The consequences were, the inability to repair damaged equipment in time, inadequate qualified personnel to maintain the sheller, and the reduction in the area occupied by rice cultivation due to intrusion from the local population. This mismanagement train derailed with economic crisis of the 1980s arrival.

\section{vi. The Inability to Self-sustain}

From the Table 2, we understand that SODERIM operated mainly due to subsidies granted by the State. However, an empowerment policy aimed at making the company functioning by its own resources (self-reliance policy) had to be put in place. This was based on high agricultural production and the market products flow. But nothing has been done in this regard. The population increased in urban areas mainly Douala, Bafoussam and Yaounde was a great market opportunity to sell SODERIM agricultural products. Unfortunately the company failed to seize this chance. 


\subsubsection{The External Determinants for the Failure of SODERIM}

\section{i. The Economic Crisis of the Late 1980s}

SODERIM mission was to train and mentor farmers for rice production, it depended entirely on State subsidies for its actions production and its products commercialization. Moreover, the profits generated by the firm were much lower than investments. Between 1986 and 1987 the prices of cash crops (coffee, cocoa, and bananas) dropped by about $50 \%$. This economic crisis has reduced State resources, and its ability to support subsidies for the company. As a result, subsidies amounting to 1200million FCFA have gradually decreased until they are completely abolished in 1988. This will later result, in the closure of the company.

\section{ii. Disengagement of the State}

In 1973, the Rice Development Mission in the Mbo plain (MIDERIM) received seven million francs for the feasibility study of the SODERIM project. Once under this name, the company had a total capital of $15,504,200,000$ FCFA. Of this amount, another 1,200million FCFA was offered each year as a grant. With the crisis of the 1980s, the State's revenues dropped considerably and that led to its inability to continue subsidizing companies. Moreover, the mismanagement of the funds received did not allow the company to create a stabilization fund that could have helped it to resist economic crisis. State subsidies remained constant from 1977 to 1981 and then began to gradually decline from 1200million FCFA in 1981 to 100 million FCFA in 1987 and finally stopped.

\subsection{The Case of the UGICAES}

\subsubsection{The Internal Determinants for the Failure of UGICAES}

\section{i. Implantation of Santchou Farmers and Grazers Union of Common Initiative Groups (UGICAES)}

UGICAES was born from the State firm collapse; SODERIM, that went bankrupt with the advent of economic crisis. There was then a reversal of territoriality since the domains formally perceived as those of the State was appropriated de facto, by local population with a bottom-top development as peasant organizations replaced State-owned companies. This is in line with Some African countries trying to consolidate some smallholder farmer activity, provide market access, and reduce risk [14]. These efforts include farmer aggregation through cooperatives, such as Githunguri Dairy in Kenya, which serves close to 40000 Farmers in East Africa; "out grower schemes", such as for barley in beer production in Ethiopia, and nucleus farms, such as Morocco's Plan Maroc vert. Lutz Goedde et al. [15]. Hence, a shift from a "top-bottom" policy in which government had the monopoly to initiate agricultural projects, to a "bottom-top" policy in which local population initiate agricultural projects. Moreover, UGICAES was born as a preventive farmer's response to SODERIM fall, as attested by this company Director Mr. YOKEUJ. B's letter addressed to the Western Province Governor pointing out that:
This union (UGICAES) whose bureau members were installed on January 26 (1995), by yourself in the appropriate premises of SODERIM, is therefore well known. For more than a year, we have been preparing it to naturally perform this task in the event that SODERIM disappears" Dongmo et al. [16].

UGICAES has benefited from SODERIM legacy: farmers trained by SODERIM to practice rice cultivation as well as the State estate landed property like the rice mill. It then acquired equipment to ensure the continuity of these activities, a husking plant and agronomic research results.

The law expediency on cooperatives and the peasant associative movement emergence framed in the act of 10 August 1992 Common Initiatives Groups (CIG). The peasant took advantage of this law to create the UGICAES under Dr YONKEUJ. B, former SODERIM director impulse. At the beginning, there were five specialized CIGs which included: market gardening CIG (tomatoes, vegetables, watermelons, soya beans, pineapple $\mathrm{CIG}$, rice $\mathrm{CIG}$, livestock CIG, UMASCIG (use of Santchou Agricultural Machinerymechanics and tractor conductors). The latter CIG was at other CIGS service, that is, to plough their plots. UGICAES receives financial support from public institutions such as the National Employment Fund (NEF) which accredited 9,000,000FCFA; the Investment Fund for Agricultural and Community Micro-projects (IFACM) which subsidized $20,000,000 \mathrm{FCFA}$. These various factors were a real spring board for UGICAES development.

It should be added that, on one hand, the environment was binding on them (the coffee break with a decline in incomes, the arable land narrowing in the Mbos plain, population growth) and on the other hand, a favorable market outlet (with the growing urban population demand for food and vegetable products offering a new market for the farmers better than cash crops one). Another non negligible asset is that, almost all the peasants are either former SODERIM employees or former UGICAES members. They have benefited from coaching or training and also have the possibility of accessing a land parcel in the former SODERIM domain, claimed by the natives through UGICAES where the State has resigned. With all these assets, and the Agricultural Firms abandonment plus available land, UGICAES embarked on a plurality of activity on the former SODERIM domain.

In line with the national effort to achieve genuine and sustainable food self-sufficiency, SODERIM was committed at making a serious contribution and further implementing actions taken in the national renewal context. SODERIM was above all a rice cultivation project, but in view to maximize profitability, fully occupied peasant and considering studies carried out, the yields obtained, diversification became essential. This agricultural development project was thus part of a policy pursued by the government to ensure the people agricultural and food independency within the framework of self-centered development defined as a priority. After its failure, comes the UGICAES, a peasant response which itself, also failed and resulting in the UGIRILCOPAM creation. 


\section{ii. Conflicting Relations Between Local Chiefs and Ugicaes}

Tensed relations between local chiefs and UGICAES emerged due to a problem of spatial expansion. This was due to the surface area occupation of about 1,000 ha requested by UGICAES from the administrative authorities. The traditional authorities shunned the UGICAES's appeal while protesting this requested piece of land. As tensions became very high, two opposing camps were formed: the UGICAES supporters and opponents. UGICAES supporters brandish the administrative authority support. FEUDJEU (2002), mentioned that;

"UGICAES is favoured by public authorities; that is why in 1997 its members sent letters to the Heads of State and the Minister of Agriculture in order to protect their interests (...). Despite this collaboration, UGICAES is not looked up favorably by the traditional authorities for whom the SODERIM closedown should be accompanied by the outright State departure (...). However, this issue should not be placed on the tribal register. While the Bamileke overwhelming weight is recognized at UGICAES the $M B O$ people are also well represented. The association is a melting pot of national tribes. Rather, it is a matter of land issues." However, the local population opposition including $\mathrm{Mr}$ PANKA and $\mathrm{Mr}$ ZEBAZE (Bamileke) to UGICAES, is justified by the fact that there is still a dispute between the State and the local population. The latter describe the transfer of their land to SODERIM as a "land scam", arguing that they had not been compensated according to the law. Furthermore, according to them, taking back their land from the State will be a land sovereignty restore on their ancestral lands. Regretting that situation, Mr. EKANGO, the then UGICAES Secretary, said:

It was a gross mistake for us, we did not understand that the local chiefs were closer to us and were more popular. We should have simply partner with them and the matter would have been resolved. Although not entirely ancestral, the $M B O$ and Bamileke (majority tribes in the UGICAES) are traditionalists. "In reality, the traditional authorities were not opposing the UGICAES activities, but rather opposing its methods of totally ignoring traditional ruler, guardians of the Mbo plain traditions and customs. By doing this, they ignore ipso facto the native wright on their ancestral land in a country where both modern and traditional land law coexist, even if they are sometimes conflictual. Moreover, the leaders mainly from the Mbo communities were not radically opposed to UGICAES, as FEUDJEU [6]. acknowledged when he wrote about the paramount chief of Santchou behavior as mentioned in the following lines: His deep intention would not be to dislodge UGICAES, but to seek a more dynamic structure, which would expand his electorate. He never came into conflict against the UGICAES, this was why we read in the peasant news paper No. 117, October 2001 that, when the UGICAES General Delegate met the paramount chief of Santchou, he proudly told him that the
CRC $C^{4}$ funding will soon arrive (17 billion Fcfa). UGICAES was asked to convene the peasants for an information meeting on 19 April 2000".

In addition, UGICAES could not perform without the traditional authority. They needed rice mil unit necessary for the paddy husking produced by the rice GIC of UGICAES. It should be noted that rice mil unit was acquired by Mbo elite during the former Soderim liquidation. With this land uncertainty, some peasants became discouraged others suspecting UGICAES to be a kind of "Screen Society" used by a group of people with expansionist desires for the late SODERIM land grabbling.

\subsubsection{The External Determinants for the UGICAES Failure: Discontinued Subventions}

The National Employment Fund (FNE) and the Investment Fund of Micro Agricultural and Community Projects (FIMAC) having stopped their loans respectively of Fcfa 9.000000 and 20.000000 per year respectively, UGICAES died by financial asphyxia.

\subsection{The Case of UGIRILCOPAM}

After the proven UGICAES bankruptcy, several peasants were again in disarray. New CIGs are being formed for the various foods production including ginger, corn, and sweet potato. In 2008, after riots due to expensive life and hunger that shook many countries, studies have been conducted to find new strategies to revive agricultural production in Cameroon. These studies reveal that in the field of rice supply in Cameroon, a growing gap exists between consumption needs and national production. Moreover, imports do not always provide necessary supply for all consumers Tazo et al. [17]. On this basis, the government has not only considered development of new sites, but above all the old rice production basins rehabilitation. It is in this regard that in 2009, MINADER launched the Pilot Program to Support the Revival of Rain Rice Production (PPARRP). This project-program that aims at revitalizing rice production in Cameroon through the use of inputs, appropriate agricultural equipment became the starting point of UGIRILCOPAM creation. But, the indicators these CIGs failure were numerous.

In this case, the determinants of failure are internal.

The evolution of subsidies granted by MINADER to UGIRILCOPAM is summarized on Table 2.

Table 2. Evolution of grants given by MINADER to UGIRILCOPAM from 2009 to 2016.

\begin{tabular}{lllll}
\hline Years & $\mathbf{2 0 0 9}$ & $\mathbf{2 0 1 0}$ & $\mathbf{2 0 1 1}$ & $\mathbf{2 0 1 2}$ \\
\hline Amount of grants & 177000000 & 107710000 & 52000000 & 20000000 \\
\hline
\end{tabular}

Source: Fact Sheet and report on the activities of UGIRILCOPAM, 2018

For the first year (2009), UGIRILCOPAM received grant $177,000,000$ from FCFA to start its activities. This made it

4CRC: Cameroon Rice Corporation. It was accompany to be created by the paramount chief of Santchou. 
possible to open the sustainability account and finance the first plots development. In 2010, funding fell by $60,000,000 \mathrm{FCFA}$ for the first crop campaign and $47,000,000 \mathrm{FCFA}$ for the second. In 2011, the amount allocated was 52,000,000FCFA and in 2012, $20,000,000 \mathrm{FCFA}$. This fourth financing is justified by the fact that in 2011, the union spent huge sums of money to buy a tractor to reduce the costs required for land development. It also equipped itself with a small sheller for the Paddy of two Threshers, Sickles, Seeders... the high cost of these expenses did not allow the union to bailout the sustainability fund as it was originally planned in 2011. This prompted them to solicit again, the help of the MINADER, in vain.

\subsection{Consequences of the Failure: Closure of Agricultural Firms and Proliferation of a Multitude of Actors on the Field}

\subsubsection{SODERIM}

The SODERIM closure was unpleasantly pronounced by a presidential decree of 08 September 1995. After its dissolution, it was wound up in 1998. The State encouraged sustainability of agricultural activity and the field exploitation through private operators. Thus, peasant organizations gathered within the UGICAES tried to take matters into their own hands. Several private operators have shown interest in the acquisition of SODERIM's assets without success. These operators include a buyer grouped under the African-American Foundation and International United Black Fund (IUBF). Many other operators have established on the said domain including:

The buyers of the rice mill

These are those who acquired SODERIM assets during its liquidation. It is essentially the aforementioned rice mill unit built on an area of 2 ha according to article 3 of the 1973 decree and materialized by a fence. This rice mill consists of the storage and shelling plant with all its contents, former management premises among others.

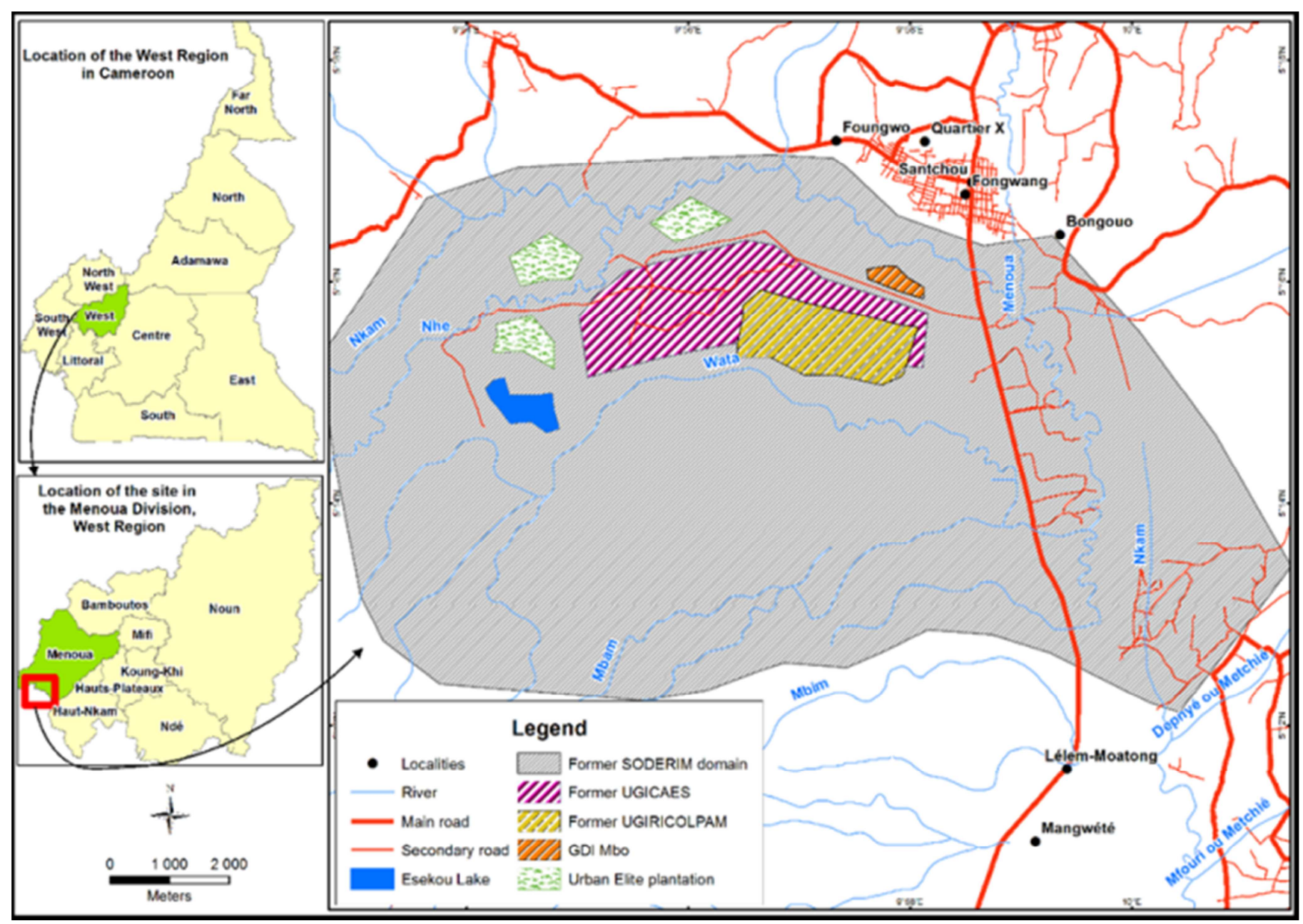

Source: author work, 2020

Figure 4. Map of the estate in 2017.

On this map, we can see the former (SODERIM 4050ha, UGICAES 2000ha, UGIRILCOPAM 800ha) and people establish by the local population.

This map shows the spatial distribution of the three firms on the land allocated to the former SODERIM.
Individual: This category of actors is made up of two types:

Those on the estate prior to the 1973 decree, including Mr. ZEBAZE (71.5ha) and Mr. PANKA (97.03ha) settled since 1971. 
Those installed on the domain after 08 September, 1995; official date of SODERIM closure.
The table 3 below illustrate the state of occupation

Table 3. Occupation state of the former Soderim domain by farmers.

\begin{tabular}{llll}
\hline People occupying the domain & Number of Ha & Activities carried & Date of occupation \\
\hline ZEBAZE & $71.5 \mathrm{ha}$ & Agriculture & 1970 \\
PANKA & $97.03 \mathrm{ha}$ & Agriculture & 1971 \\
Mr. EBOLO & $80 \mathrm{ha}$, & Agriculture & 1996 \\
KENFACK & $58 \mathrm{ha}$ & Picbreeding & 1998 \\
ELAT & $20 \mathrm{ha}$ & Fishery & 1998 \\
DJOLLA & $105 \mathrm{ha}$ & Agriculture & 1998 \\
TIMO & $301 \mathrm{ha}$ & Agriculture & 1997 \\
EKANGA & $10 \mathrm{ha}$ & Honey & 2005 \\
Others smallest peasants & Less than 5ha & Agriculture & Different years \\
\hline
\end{tabular}

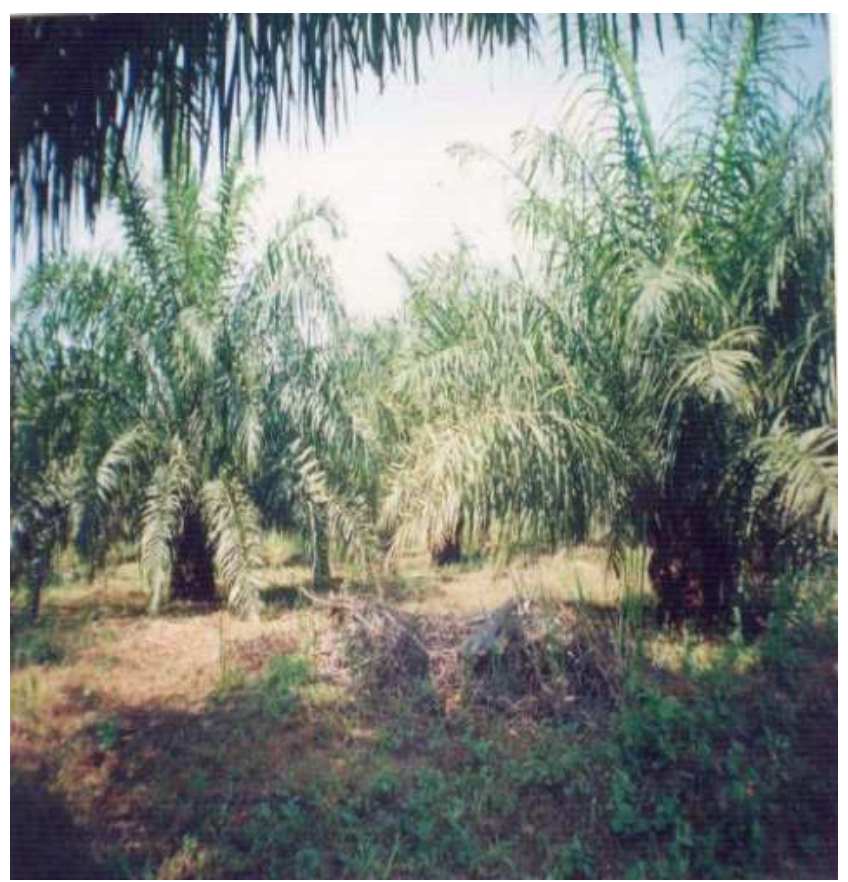

Figure 5. Palm trees on the former SODERIM land.

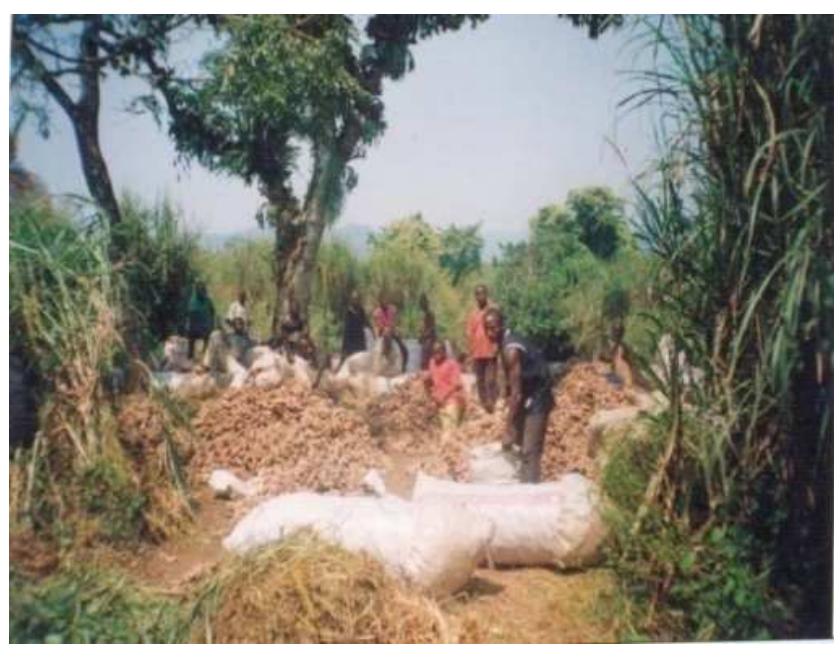

Author's Fieldwork, 2017.

Figure 6. "ginger" harvest on the former SODERIM land.

There are many medium farms too (Mr. Ebolo 82ha, Mr.
KENFACK 78 ha etc.) and small farms (Mr. ELAT 20ha, Mr. DJOLLA 25ha etc.). They constitute the urban elites. Then those whose areas are less than 05ha, constitute the greatest proportion. The figures 5 and 6 below shows the type of agricultural activities carried on the domain mainly, perennial and seasonal crops.

Figures 5 and 6 shows respectively, two types of crops: A palm tree plantation, more than 301 ha cultivated by $\mathrm{Mr}$. TIMO (figure 5) and a ginger farm of 55ha (figure 6), this palm farm, a perennial culture, illustrates the territorial appropriation mechanism used by some stakeholders on the domain. These are real indicators of land appropriation developed by Mr. Djolla on an "unclear status" land.

\subsubsection{UGICAES}

The UGICAES failure is spatially verified by the activities abandonment. The 1000ha entrusted to them by the administration are now occupied by other farmers, formerly not members of the Union. Legally, the CIGS that made up the Union were dissolved and some former members created a new union called the UGIRILCOPAM.

Given the multiplicity of actors in the field, as the SODERIM, UGICAES, and UGIRILCOPAM bankruptcy, what lessons can be drawn?

\section{Lessons to Be Learned from the Failure of These Firms}

The first lesson to be learned is the companies "mismanagement". The diversions show that of the 2,950,000,000FCFA grants awarded to SODERIM, $1,239,872,962$ FCFA was embezzled, i.e. $42 \%$ of the total amount allocated. Which if well invested, this overwhelming sum of money would have avoided the company bankruptcy by anticipating, periods of economic crisis.

The second lesson is, the early purchase of material before the actual production; it is placing plough machine before the oxen. It is totally incomprehensible for a company where profitability must be the key word that, equipment is ready (a sheller with a capacity of 12000 tons while the production was only 500 tons with a deficit of 11500tons) before the agricultural production itself. In addition, the production is far below the operating 
capacity of the said machines. This is in total contradiction with Mideksa [19], advocating that, the performance of firm or decision-making unit is common to describe them in terms of 'productivity' or 'efficiency'." We believe sufficient production must first be made before purchasing machinery whose operating capacity is proportional to agricultural production.

Avoid fanciful recruitments in Para public companies that are always unproductive at long-term, leading to the company close up.

For UGICAES and UGIRILCOPAM, funding cuts brought about their failure.

Whether SODERIM, UGICAES or UGIRILCOPAM, a system of progressive financial empowerment could be put in place to avoid permanent financial infusion i.e. no longer depending solely on subsidies granted by the State; because weaned from these subsidies, the company dies of "financial suffocation". A policy of financial stabilization could be put in place. This goes in line with Eze [18]., who stated that the objective of Agricultural financing policies is to establish an effective system of sustainable agricultural financing schemes, programs and institutions that could provide micro and macro credit facilities for the micro small medium and large scale producers, processors and marketers"

The local development sought by the various financing had been drowned in the embezzlement, in the inability to empower firms despite the heavy sums received from the various financial institutions. It is necessary for the State to clearly define the lands status allocated to State corporations to avoid land disputes situations opposing the UGICAES, farmers, local chiefs and the State about the fate of the late SODERIM's land so that this chiaroscuro should not happen again.

\section{Conclusion}

It was in a less favorable international and national context and due to the 1990 law on freedom of association in Cameroon that SODERIM, UGICAES and UGIRILCOPAM were respectively created. The agricultural policy of the Cameroonian State centered on subsidies has shown by its limitations that almost all agroindustrial zones and Peasants' Organizations (POs) fell into bankruptcy once cut off from the said aid. The agricultural projects financing was not automatically a guarantee of local development in the Mbos plain; since local development has not lived up to the funding granted. Also, funding is still not a guarantee of agricultural performance, which explains the fall and then the closure of these three firms, due to internal and external determinants. Currently, private actors occupy their former domains. The determinants for these bankruptcies ranged from the misappropriation of aid allocated to them, lack of a real policy of empowerment, to the vagueness of the land status of these firms' former domains, sources of quarrels between the natives and the POs. We believe that aid granted to State companies or POs should be in a process of progressive empowerment, and the funds allocated should be subjected to control and monitoring. It is the pathway for subsidies to be a guarantee of local development so much sought after, with agriculture as its base.

\section{References}

[1] World Bank 1998. World Development Report 1998/1999: Knowledge for Development. New York: Oxford University Press. (C) World Bank.

[2] Yaron, J., Benjamin, M., Piprek, G., (1997). Rural finance: Issues, design, and best practices. Environmentally sustainable development studies and Monographs series, The World Bank, Washington, D. C.

[3] Kuou Ebongue I. A. (2007), Disengagement of State from SODERIM and the emergence of new actors of development in Santchou subdivision (Western Province Cameroon), Master's thesis in Geography, University of Yaoundé I. 152.

[4] Malango Kitungano J-L. (2007), Les théories technologiques explicatives de la crise des entreprises publiques congolaise, Mémoire de Master en Sciences politiques et administratives, Université De Lubumbashi, RDC, 110p.

[5] Ediamam Epalle G. M. (2008) the land issues of the former domain of the Rice Development Society in the Mbo plain (SODERIM) West Cameroon. Master's thesis in Geography, University of Dschang. 128p.

[6] Feuddjeu G. B. (2002) peasant organizations and food security: the case of rice-growing peasant organizations of west region of Cameroon. DEA dissertation in Geography, University of Dschang. 143p.

[7] Elong J. G. (2005), Organisations paysannes et construction des pouvoirs dans le Cameroun forestier. Yaoundé, PUY, $134 \mathrm{p}$.

[8] Suleiman Abu. (2019): Agricultural Financing and economic Development in Nigeria. An ARDL Approach On AGSF Roles. Www.ResearchGate.net. Consulted online 14/10/2020.

[9] Kegne Fodouop (2003), Développement rural dans la province du Centre. Les cahiers d'outre-mer, N²21, pp 87-102.

[10] Elong, J. G. and Mbanga, L. A. (2009) "Improving collective rural infrastructure through community participation in Ngoketunjia Division, North West Region, Cameroon”. In Revue Internationale des Arts, Lettres et Sciences Sociales. Vol $1 \mathrm{~N}^{\circ} 3$. Pp 225-246.

[11] Fongang Fouepe G. H. (2018), Enquête sur le suivi des dépenses agricoles du Cameroun, rapport de mission effectuée du 05 au 09 mai 2008. FAO-UANEPAD, 17p.

[12] Ediamam Epalle and Elat (2016): From SODERIM to UGICAES in the Mbo plain: questioning the sustainability of agriculture in the light of changes in agricultural policies. In knowledge and rural finance policies in sub-Saharan Africa. Questions to some perspectives for African rural entrepreneurs. Editions CLE, Yaoundé, p331-334.

[13] Tchekote H. et Tallet B. (2016): Les organisations paysannes (OP), entre construction de pouvoirs et émergence de nouveaux territoires dans l'ouest Cameroun. In savoirs et politiques de financement rural en Afrique subsaharienne. Editions CLE, Yaoundé, p331-334. 
[14] Guillermou. Y. (2016): Paysans, encadrement étatique et appuis extérieurs: quelles voies pour un développement durable? In savoirs et politiques de financement rural en Afrique subsaharienne. Editions CLE, Yaoundé, p331-334.

[15] Lutz Goedde \& all, (2019), Winning in Africa's agricultural market. McKinsey's Denver office. Nairobi, Kenya.

[16] Dongmo. J. L, Tazo. E, Feudjeu. G. B. (2001): Emergence of UGICAES on a part of the SODERIM estate in liquidation in Santchou (West-Cameroon): explanation of a revenge of peasant agriculture on agro-industry in an immigration zone. Annales of the FASH University of Ngaoundéré, vol VI p524.

[17] Tazo. E, Miendjiem. I. L, Ediamam Epalle G. M. (2010): land issues and the problematic of the revival of agricultural activities on the former SODERIM land (West-Cameroon) In multidisciplinary views on land conflicts and their socioeconomic political impacts in Cameroon. Laboratory of Sustainable Development and Territorial Dynamics, University of Montreal. Vol 10. P175-187.

[18] Eze Christopher et all. (2018): Agricultural financing policies and rural development in Nigeria. The 84th Annual Conference of the Agricultural Economics Society Edinburgh. 20p.

[19] Mideksa Dabessa Iticha (2020): Review on Determinants of Economic Efficiency of Smallholder Maize Production in Ethiopia. International Journal of Agricultural Economics. Vol. 5, No. 4, 2020, pp. 123-132. doi: 10.11648/j.ijae.20200504.15. 